\title{
PERANCANGAN SISTEM MONITORING DAN EVALUASI BANTUAN USAHA PERTANIAN PADA KEMENTERIAN PERTANIAN RI
}

\author{
Yohannes Kurniawan; Devyano Luhukay; Titan \\ Information Systems Department, School of Information Systems, Binus University \\ Jl. K.H. Syahdan No. 9, Palmerah, Jakarta Barat 11480 \\ ykurniawan@binus.edu; devyano@binus.edu; titan@binus.edu
}

\begin{abstract}
The main problems of current system in agriculture ministry is sub-optimal information retrieval of realization and development of agriculture capital and production facilities subvention. Therefore, this research aims to analyze and design information system for monitoring and evaluation of subvention of agriculture capital and production facilities. This information system is developed based on internet technology to help the main team (agriculture minister and technical team of directorate agriculture department), coach team of provincial agriculture office, and technical team of district/city agriculture office to access the accurate information related realization and development of agriculture business any where and any time. It is designed with OOAD (object oriented analysis and design) method by using UML notation (use case diagram, class diagram, component architecture and user interface design). This research produces a design of information system for subvention monitoring and evaluation of agriculture capital and production facilities for the ministry of agriculture RI.
\end{abstract}

Keywords: analysis, design, system, monitoring, evaluation

\begin{abstract}
ABSTRAK
Masalah yang dihadapi oleh kementerian pertanian saat ini adalah penelusuran informasi realisasi dan perkembangan atas bantuan sarana produksi dan modal usaha pertanian yang belum optimal. Maka dari itu, penelitan ini bertujuan untuk menganalisis dan merancang sistem informasi monitoring dan evaluasi bantuan sarana produksi dan modal usaha pertanian. Ini merupakan sistem berbasis internet untuk mempermudah Tim Pusat (Menteri Pertanian dan Tim Teknis Direktorat Jenderal), Tim Pembina Dinas Pertanian Propinsi, dan Tim Teknis Dinas Pertanian Kabupaten/Kota untuk mengakses informasi realisasi dan perkembangan atas bantuan usaha pertanian dengan akurat tanpa dibatasi ruang dan waktu. Perancangan sistem informasi dilakukan dengan metode OOAD (object oriented analysis and design) dengan notasi UML yang meliputi: use case diagram, class diagram, dan component architecture, beserta perancangan user interface. Penelitian ini menghasilkan sebuah perancangan sistem informasi monitoring dan evaluasi bantuan sarana produksi dan modal usaha pertanian bagi kementrian pertanian RI.
\end{abstract}

Kata kunci: analisis, perancangan, sistem, monitoring, evaluasi 


\section{PENDAHULUAN}

Perkembangan teknologi informasi yang sangat cepat telah mempengaruhi kehidupan manusia di berbagai bidang. Salah satu manfaat teknologi informasi adalah untuk menyebarkan informasi. Dengan memanfaatkan jaringan komputer, penyebaran informasi dapat dilakukan dengan mudah. Selain itu, penyebaran informasi juga dapat dilakukan secara global dengan jaringan komputer yang sangat besar, yang dikenal dengan internet. Melalui internet, informasi dapat disampaikan ke semua penjuru dunia. Dengan memanfaatkan internet, suatu perusahaan dapat mengirim informasi ke kantor cabang yang lokasinya berjauhan, baik itu dalam satu propinsi maupun propinsi lain, dengan sangat mudah dan cepat. Selain mudah dan cepat, penggunaan internet dapat menekan biaya operasional perusahaan. Hal tersebut dimanfaatkan secara menyeluruh oleh tiap departemen pemerintahan dalam menjalankan tugasnya.

Kedudukan sektor pertanian dalam pembangunan ekonomi nasional cukup nyata, dilihat dari proporsinya terhadap pendapatan nasional. Menurut data dari Direktorat Jenderal Tanaman Pangan Kementrian Pertanian, Pemerintah Republik Indonesia melalui Kementrian Pertanian menetapkan aksi program Peningkatan Produksi Beras Nasional (P2BN) sebesar dua juta ton beras untuk 2007, dan selanjutnya kenaikan 5\% untuk setiap tahunnya sampai 2009. P2BN yang mendukung ketahanan pangan, ditargetkan supaya surplus beras nasional pada kondisi aman dan stok beras di Bulog bertambah satu juta ton, sehingga harga beras lebih mudah dikontrol. Menurut data Direktorat Jenderal Tanaman Pangan tersebut, Program P2BN (Peningkatan Produksi Padi dan Jagung) ini dilakukan melalui pemberian benih padi, jagung, dan kedelai secara gratis kepada petani yang memenuhi syarat dan ketentuan yang berlaku baik secara administrasi maupun teknis. Kegiatan ini melibatkan alokasi anggaran sebesar 21,4 triliun dari APBN 2009 untuk subsidi langsung dan spesifik dalam bentuk bantuan, baik pupuk, benih, maupun bunga kredit baik untuk dilakukan tetapi yang penting pelaksanaannya harus dapat dipertanggungjawabkan. Oleh karena itu, diperlukan sebuah media monitoring dan evaluasi yang efektif untuk penyaluran benih padi dan jagung bagi anggota kelompok tani.

Sampai sekarang, belum ada aplikasi yang menangani proses monitoring dan evaluasi (monev) pemberian subsidi kepada petani, sehingga menyulitkan pemerintah pusat dalam melakukan proses monev bantuan yang telah tersalurkan kepada petani. Monitoring merupakan program yang terintegrasi, bagian penting dipraktek manajemen yang baik dan arena itu merupakan bagian integral di manajemen sehari-hari (Vincent, 2006, p21). Sedangkan evaluasi merupakan salah satu fungsi dari manajemen program, evaluasi dilakukan terhadap seluruh atau sebagian unsur-unsur program serta terhadap pelaksanaan program. Evaluasi program harus dan dapat diselenggarakan secara terus menerus, berkala, dan atau sewaktu-waktu (Vincent, 2006, p28).

Saat ini proses monev masih dilakukan secara konvensional sehingga memerlukan waktu yang lama untuk melakukan verifikasi dan sulit untuk mengontrol apakah bantuan telah dimanfaatkan dengan tepat dan bagaimana perkembangan bantuan sarana produksi yang telah diberikan. Sarana produksi yang dimaksud disini merupakan sarana benih tanaman, pupuk, dan obat-obatan, termasuk peralatan pengolahan tanah, peralatan pengairan, dan peralatan lainnya yang mendukung pengembangan usaha tani (Daniel, 2001, p26). Sedangkan modal usaha adalah biaya yang digunakan untuk pendidikan, pelatihan, upah tenaga kerja, pembelian bahan baku, bahan pendukung, dan media tumbuh (Daniel, 2001, p34).

Selain itu belum adanya integrasi data antara kabupaten, pusat, dan propinsi dalam melakukan monev bantuan sarana produksi dan modal usaha pertanian. Proses monev juga dibutuhkan untuk mengelola content dari informasi, termasuk mendefinisikan skema dan operasi berjalan untuk menyakinkan informasi yang ada berkualitas (Vassiliadis et al., 2001). Pada dasarnya informasi dapat 
menjadi berkualitas dengan adanya pengukuran yang dilakukan secara berkala (Basili and Caldiera, 1995). Melihat pentingnya proses Monitoring dan Evaluasi dalam menunjang aktifitas pemerintah dalam hal penyaluran bantuan disektor pertanian, perlu dilakukan analisis dan perancangan sistem informasi monitoring dan evaluasi bantuan sarana produksi dan modal usaha pertanian Kementrian Pertanian Republik Indonesia. Dengan adanya sistem monitoring dan evaluasi ini, diharapkan proses penyaluran bantuan sarana produksi dan modal usaha pertanian dan perkembangan usaha pertanian dapat dimonitor dan dievaluasi dengan lebih baik lagi.

\section{METODE}

Metode yang digunakan dalam penulisan makalah ini adalah tinjauan pustaka, analisis dan perancangan guna membangun sistem informasi monitoring dan evaluasi bantuan sarana produksi dan modal usaha pertanian. Langkah awal di dalam melakukan analisis adalah dengan melakukan survei atas sistem yang sedang berjalan. Data yang dikumpulkan didapatkan langsung dari objeknya, dengan berkunjung ke Pusat Data dan Informasi Kementrian Pertanian RI, B2P2TP Bogor, dan Dinas Pertanian Kabupaten Karawang, wawancara dilakukan dengan cara melakukan tanya jawab langsung dengan kepala dan staf bidang pengembangan sistem informasi Pusat Data dan Pengembangan Sistem Informasi Kementrian Pertanian RI, kepala dan staf seksi evaluasi B2P2TP, dan bagian data dan informasi Dinas Pertanian Kabupaten Karawang, lalu analisis terhadap hasil survei atau field study dan identifikasi kebutuhan bagi kementerian pertanian agar sistem dapat berjalan lebih baik, dan terakhir adalah identifikasi persyaratan sistem. Dokumentasi dari hasil analisis menggunakan unified modeling language yang didasarkan pada unified process disciplines (Satzinger, 2005), seperti use case diagram, class diagram, dan component architectur. Hasil analisis kemudian digunakan untuk perancangan sistem yang diusulkan berupa user interface.

\section{HASIL DAN PEMBAHASAN}

\section{Tata Laksana Sistem Berjalan}

Kementerian Pertanian Republik Indonesia merupakan salah satu kementerian milik pemerintah yang bertugas untuk membantu Presiden dalam menyelenggarakan sebagian urusan pemerintahan di bidang pertanian, mempunyai beberapa kantor cabang di daerah. Kantor-kantor cabang ini menggunakan sarana seperti e-mail, chatting, dan telepon dalam melakukan komunikasi dengan kantor pusat. Saat ini, Kementerian Pertanian RI ingin membuat jalur komunikasi dengan kantorkantor cabang di daerah tersebut melalui jalur internet khususnya dalam hal koordinasi agar lebih cepat dan efisien dengan kantor pusat.

Tata laksana proses pelaporan yang terkait dengan pelaporan dari bantuan sarana produksi dan modal usaha pertanian yang diberikan oleh pemerintah pusat sebagai berikut, Gapoktan (Gabungan Kelompok Tani) penerima bantuan akan menerima bantuan modal untuk pengembangan usaha pertanian dan pemberdayaan masyarakat sekitarnya. Setelah bantuan tersebut diterima oleh Gapoktan, maka akan dilakukan pelaporan sebagai instrumen pertanggungjawaban pengelolaan dan pemanfaatan dana oleh Gapoktan. Pelaporan pelaksanaan kegiatan pemberdayaan dan pengembangan agribisnis Gapoktan dilaksanakan secara berjenjang dan terus-menerus. Gapoktan wajib membuat laporan pendataan bantuan, dengan jangka waktu maksimal 2 bulan setelah alokasi bantuan pertanian. Setelah itu Gapoktan terpilih dan petugas pendamping akan menyampaikan laporan bulanan kepada Tim Teknis tingkat Kabupaten/Kota dan laporan triwulan kepada Tim Teknis Direktorat Jenderal selaku penggungjawab kegiatan. Selain itu Tim Teknis tingkat Kabupaten/Kota akan menyampaikan laporan 
triwulan kepada Tim Pembina tingkat Propinsi. Tim Pembina Propinsi akan menyampaikan menyampaikan laporan kepada Tim Pusat. Berdasarkan laporan triwulan dari setiap propinsi, Tim Pusat menyampaikan laporan triwulan kepada Menteri Pertanian. Secara skematis mekanisme pelaporan pemberdayaan dan pengembangan usaha agribisnis digambarkan pada Gambar 1.

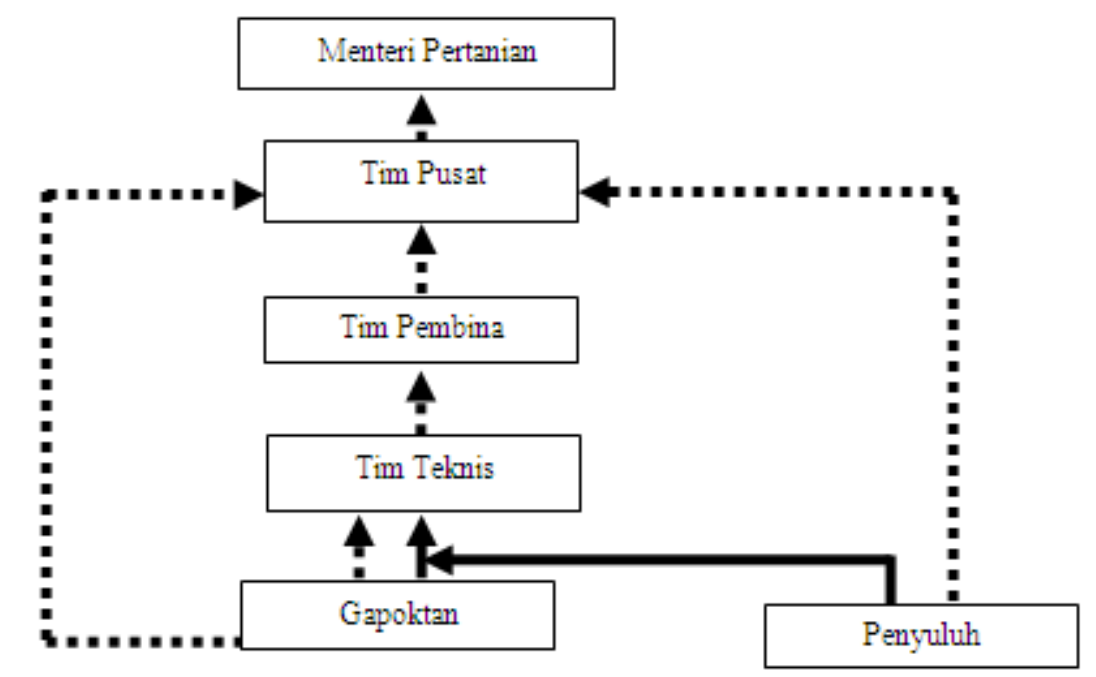

Laporan Bulanan

Laporan Triwulan

Gambar 1 Mekanisme pelaporan periodik (Kementrian Pertanian, 2008)

Dalam rangka monitoring dan evaluasi kegiatan penyaluan bantuan dan perkembangan usaha tani, perlu dibuat pelaporan oleh pelaksana dan penangungjawab kegiatan. Laporan dibuat berjenjang Dinas Pertanian Kabupaten/Kota, Dinas Pertanian Propinsi, dan Direktorat Jenderal. Laporan ini bertujuan untuk mengawasi dan mengevaluasi pelaksanaan kegiatan agar dapat mencapai sasaran dan tujuan yang ditetapkan. Selain itu laporan juga berfungsi sebagai masukan untuk perbaikan program dan kegiatan tersebut dimasa datang.

Pelaksanaan monitoring dan evaluasi dilakukan dalam periode waktu yang telah ditentukan (bulananan atau triwulan) dalam sistematika pelaporan berjenjang. Hal ini menjadikan proses monitoring dan evaluasi menjadi lambat, dikarenakan keterbatasan waktu dan tempat didalam melaporkan setiap kegiatan perkembangan usaha tani (agribisnis). Keterbatasan ini menyebabkan informasi yang diperoleh menjadi kurang optimal.

Dalam proses pelaporan pendataan realisasi dan perkembangan kegiatan agribisnis harus dilakukan secara tepat waktu. Untuk bisa menilai kinerja Gapoktan yang ada maka dibutuhkan penilaian yang objektif terhadap masing-masing Gapoktan. Pada sistem yang digunakan, kinerja Gapoktan terkait dengan pelaporan yang dilakukan akan dinilai berdasarkan dua kriteria, yaitu: ketepatan pelaporan realisasi bantuan, ketepatan pelaporan perkembangan kegiatan agribisnis (bulanan atau triwulan). Selain ketepatan waktu juga akan dilakukan perhitungan produktivitas Gapoktan, beserta actual varians (rencana-alokasi dan alokasi-realisasi).

Berdasarkan data-data yang didapat, perhitungan ketepatan waktu pelaporan produktivitas, dan actual varians dilakukan sebagai berikut: (1) ketepatan Waktu Pelaporan, mencakup ketepatan Pelaporan Realisasi Bantuan Sarana Produksi dan Modal Usaha Pertanian dan ketepatan Pelaporan 
Perkembangan Agribisnis (bulanan dan triwulan); (2) produktivitas fisik (Usaha Tani), merupakan konsepsi efisiensi usaha (fisik) dengan kapasitis tanah. Efisiensi fisik mengukur banyaknya hasil (output) yang diperoleh dari satuan input yang diberikan, dan (3) actual varians yang dilakukan untuk membandingkan antara tingkat alokasi bantuan atau subsidi sarana produksi dan modal usaha pertanian yang diterima oleh Gapoktan dengan rencana pelaksanaan kegiatan usaha tani (agribisnis), serta membabdingkan tingkat realisasi atau pemanfaatan bantuan atau subsidi sarana produksi dan modal usaha pertanian yang dimanfaatkan oleh Gapoktan dengan alokasi bantuan yang diterima oleh Gapoktan.

\section{Permasalahan yang Dihadapi}

Berdasarkan analisis terhadap tata laksana sistem berjalan, diketahui permasalahan yang dihadapi sebagai berikut: (1) sulitnya pemerintah pusat dan propinsi dalam melakukan pemantauan transaksi penyaluran dan perkembangan bantuan sarana produksi dan modal usaha pertanian, karena aliran pelaporan yang mengalir dari Kabupaten/Kota, diteruskan ke propinsi, dan selanjutnya ke pemerintah pusat masih dilaksanakan secara manual dengan pola pelaporan berjenjang; (2) sulitnya melakukan pencarian dan penelusuran informasi terhadap bantuan sarana produksi dan modal usaha pertanian yang telah terealisasi, karena informasi yang diperoleh pemerintah pusat dan propinsi based on paper, sehingga sulit melakukan drill down dari informasi yang ada, terkait dengan realisasi dan perkembangan usaha agribisnis.

\section{Usulan Pemecahan Masalah}

Berdasarkan analisis terhadap masalah yang teridentifikasi, diusulkan alternatif pemecahan masalah, yakni menganalisis dan merancang sistem informasi monitoring dan evaluasi bantuan sarana produksi dan modal usaha pertanian yang mampu untuk: (1) membuat pencatatan realisasi dan perkembangan usaha agribisnis bantuan sarana produksi dan modal usaha pertanian; (2) menyajikan kumpulan informasi transaksi dan permasalahan pada tingkat operasional yang berguna bagi proses monitoring dan evaluasi bantuan sarana produksi dan modal usaha pertanian yang dapat di drill-down dan diakses secara real time; (3) melakukan pengolahan data untuk pembuatan dan penyajian laporan dengan cepat dan mudah, yang didukung oleh data yang telah diintegrasikan antara Dinas Pertanian Kabupaten/Kota, Dinas Pertanian Propinsi, dan Departemen Pertanian Pusat.

\section{Fitur-fitur yang Diusulkan}

Fitur-fitur dari sistem informasi yang diusulkan dapat dilihat pada Tabel 1.

Tabel 1 Fitur-fitur Sistem Informasi Monitoring dan Evaluasi Bantuan Sarana Produksi dan Modal Usaha Pertanian

\begin{tabular}{|c|c|c|}
\hline Kebutuhan & Fitur & Keterangan \\
\hline \multicolumn{3}{|c|}{ Monitoring dan Evaluasi } \\
\hline \multicolumn{3}{|c|}{ Tahap Perencanaan (Ex-Ante) } \\
\hline Hasil Analisis & $\begin{array}{l}\text { Laporan rekapitulasi rencana bantuan } \\
\text { sarana produksi dan modal usaha } \\
\text { pertanian yang dapat di drill-down dan } \\
\text { Laporan evaluasi rencana usaha tani } \\
\text { yang diterima dan ditolak. }\end{array}$ & $\begin{array}{l}\text { Laporan yang berisi rekapitulasi rencana } \\
\text { bantuan sarana produksi dan modal usaha } \\
\text { pertanian yang dapat di drill-down untuk } \\
\text { menampilkan informasi lebih rinci. Misalnya } \\
\text { laporan tingkat propinsi Jawa Barat yang dapat } \\
\text { dilihat lebih rinci per Kabupaten/Kota, } \\
\text { kemudian dapat dilihat lebih rinci lagi per } \\
\text { kecamatan, dan per Gapoktan. } \\
\text { Mengukur apakah pelaporan realisasi } \\
\text { penyaluran bantuan telah dilaporkan atau } \\
\text { belum. Light indikator akan berwarna: merah }\end{array}$ \\
\hline
\end{tabular}




\begin{tabular}{|c|c|c|}
\hline & & $\begin{array}{l}\text { jika pelaporan }<50 \% \text {, kuning jika pelaporan } \\
50 \%-75 \% \text {, dan hijau jika pelaporan }>75 \% \text {. }\end{array}$ \\
\hline \multicolumn{3}{|c|}{ Tahap Pelaksanaan (On-Going) } \\
\hline \multirow[t]{4}{*}{ Hasil Analisis } & $\begin{array}{l}\text { Laporan rekapitulasi realisasi } \\
\text { penyaluran bantuan sarana produksi dan } \\
\text { modal usaha pertanian yang dapat di } \\
\text { drill-down dan Laporan evaluasi } \\
\text { perkembangan usaha tani (bulanan dan } \\
\text { triwulan Gapoktan). }\end{array}$ & $\begin{array}{l}\text { Laporan yang berisi rekapitulasi penyaluran } \\
\text { bantuan (alokasi) sarana produksi dan modal } \\
\text { usaha pertanian yang dapat di drill-down untuk } \\
\text { menampilkan informasi lebih rinci. Misalnya } \\
\text { laporan tingkat propinsi Jawa Barat yang dapat } \\
\text { dilihat lebih rinci per Kabupaten/Kota, } \\
\text { kemudian dapat dilihat lebih rinci lagi per } \\
\text { Gapoktan. }\end{array}$ \\
\hline & $\begin{array}{l}\text { Laporan rekapitulasi Perkembangan } \\
\text { usaha agribisnis (Bulanan dan } \\
\text { Triwulan Gapoktan) yang dapat di drill- } \\
\text { down. }\end{array}$ & $\begin{array}{l}\text { Laporan perkembangan bantuan sarana } \\
\text { produksi dan modal usaha pertanian yang dapat } \\
\text { di drill-down. Dalam laporan ini akan dicatat } \\
\text { realisasi dan perkembangan dari bantuan serta } \\
\text { permasalahan yang ada dalam perkembangan } \\
\text { usaha tani. }\end{array}$ \\
\hline & Absensi pelaporan & $\begin{array}{l}\text { Absensi dilakukan terhadap data dasar rencana } \\
\text { kegiatan pertanian, dan data triwulan ke } 1,2,3 \text {, } \\
\text { dan } 4 \text {. }\end{array}$ \\
\hline & Permasalahan operasional. & $\begin{array}{l}\text { Menampilkan informasi permasalahan yang } \\
\text { terdapat pada level operasional (Gapoktan dan } \\
\text { Penyuluh Pendamping) dam menampilkan } \\
\text { status informasi permasalahan operasional yang } \\
\text { telah diselesaikan ataupun belum. }\end{array}$ \\
\hline \multicolumn{3}{|c|}{ Tahap Pasca-Pelaksanaan (Ex-Post) } \\
\hline \multirow[t]{3}{*}{ Hasil Analisis } & Monitoring kegiatan agribisnis & $\begin{array}{l}\text { Melakukan monitoring terhadap perkembangan } \\
\text { kegiatan agribisnis (Rp.) terhadap masing- } \\
\text { masing Gapoktan setiap triwulan. }\end{array}$ \\
\hline & $\begin{array}{l}\text { Laporan evaluasi akhir kegiatan } \\
\text { (produktivitas) }\end{array}$ & $\begin{array}{l}\text { Laporan yang digunakan untuk menampilkan } \\
\text { rekapitulasi produktifitas per propinsi, yang } \\
\text { dapat di drill-down per Kabupaten/Kota, dan } \\
\text { per Gapoktan sesuai dengan periode yang } \\
\text { dipilih. }\end{array}$ \\
\hline & & $\begin{array}{l}\text { Beserta evaluasi Gapoktan, penyuluh } \\
\text { pendamping, kelembagaan ekonomi, dan } \\
\text { kegiatan agribisnis. }\end{array}$ \\
\hline
\end{tabular}

Fitur-fitur dari sistem informasi yang diusulkan digambarkan sesuai dengan Gambar 2, di mana akan ada 5 (lima) actor, Tim Teknis Dinas Pertanian Kabuapaten/Kota, Propinsi, Direktorat Jenderal, Admin (Pusdatin Pertanian), dan menteri pertanian, yang akan saling berbagi tanggung jawab di dalam menggunakan sistem informasi monitoring dan evaluasi ini.

Kebutuhan data monitoring dan evaluasi bantuan sarana produksi dan modal usaha pertanian dari kementerian pertanian digambarkan melalui class diagram lihat Gambar 3. 


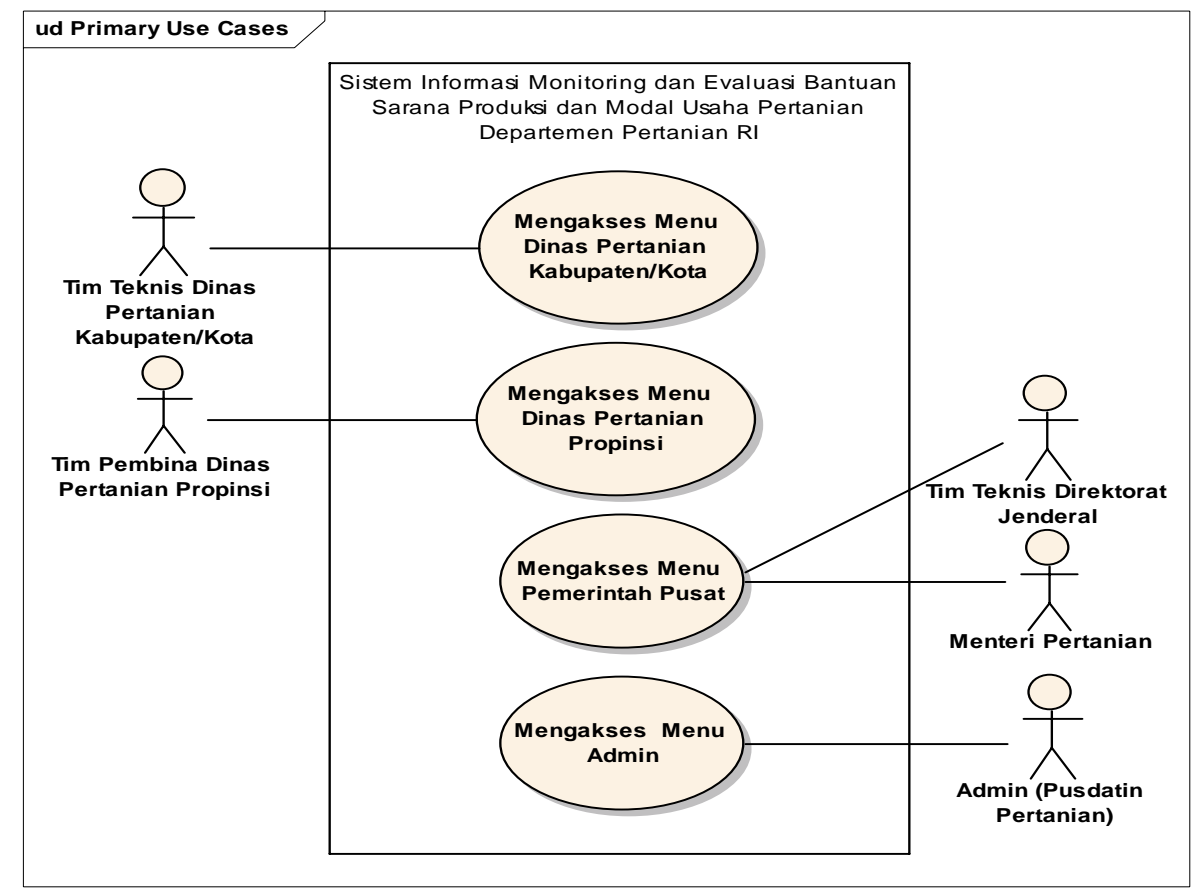

Gambar 2 Use case diagram

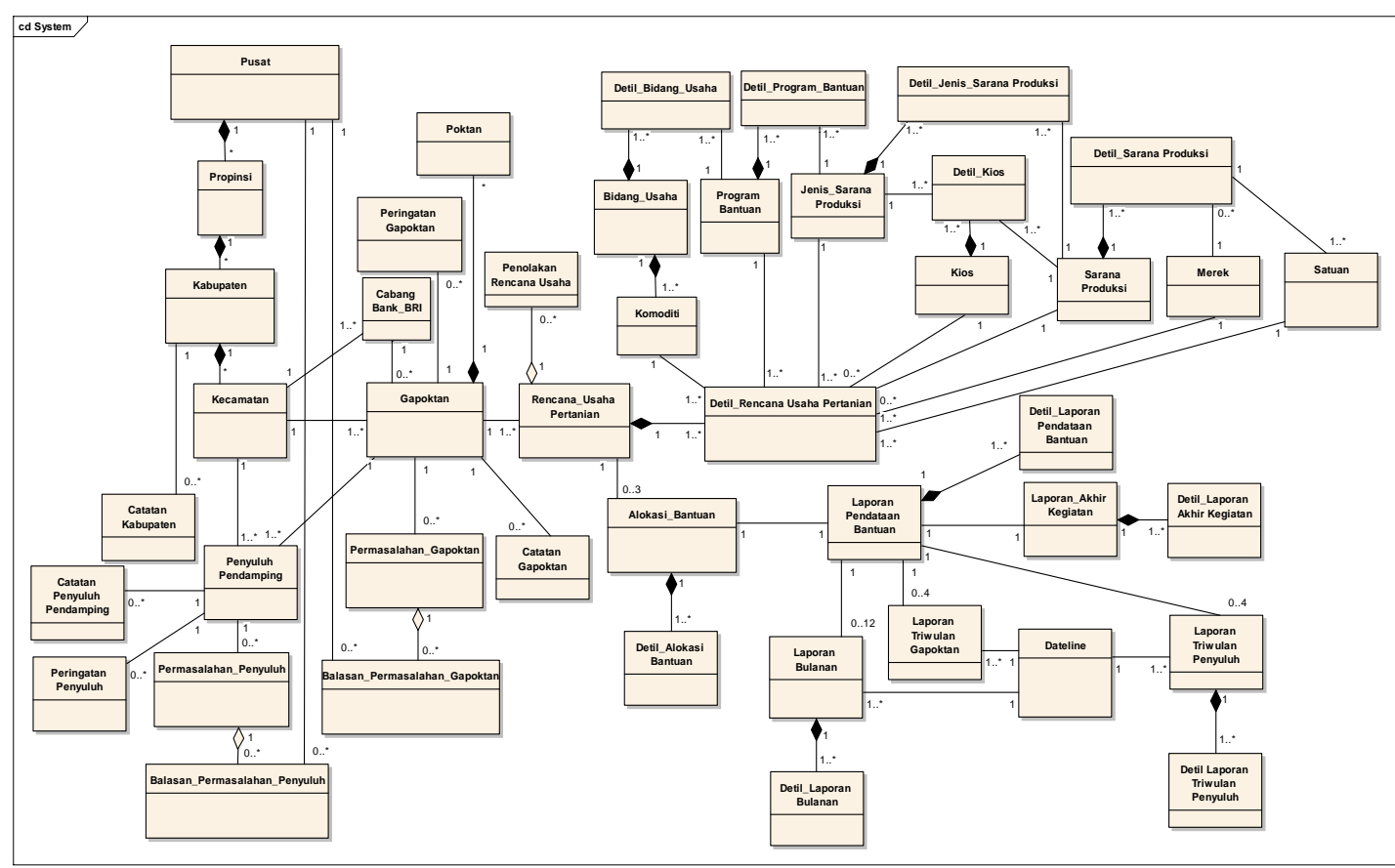

Gambar 3 Class diagram

\section{Rancangan Layar}

Rancangan user interface yang dibuat dalam pembangunan sistem informasi monitoring dan evaluasi bantuan sarana produksi dan modal usaha pertanian adalah sebagai berikut (Gambar $4-8$ ): 
Gambar 4 menampilkan halaman Monev tingkat Nasional. Menteri pertanian dapat memilih subsektor, program bantuan, dan periode. Tim Teknis Direktorat Jenderal dapat memilih program bantuan dan periode. Menteri Pertanian atau Tim Teknis Direktorat Jenderal memilih tipe laporan yang ingin dipilih, melalui link yang tersedia. Sistem akan memverifikasi input-an. Selanjutnya, sistem menampilkan informasi detil laporan Monev secara nasional (per propinsi) pada halaman yang lain.

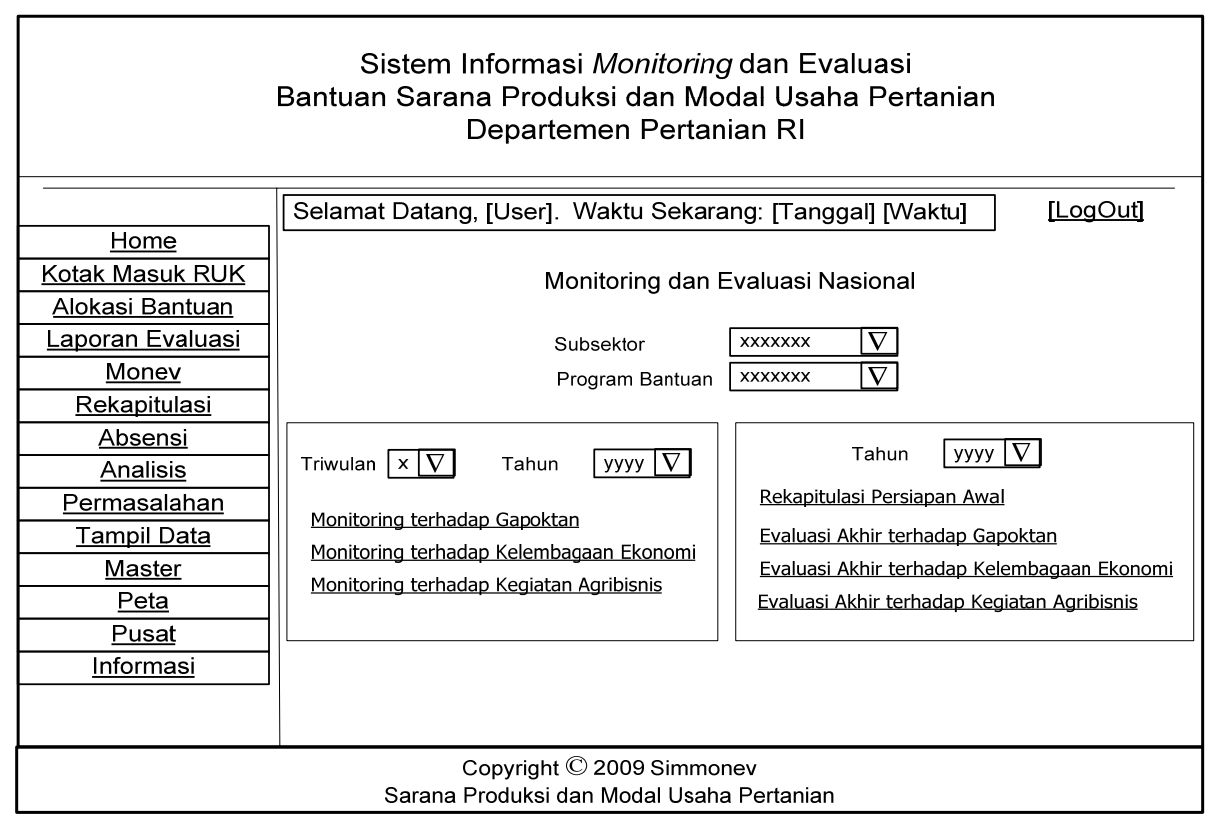

Gambar 4 Rancangan user interface pelaporan monitoring dan evaluasi nasional

Gambar 5 menampilkan halaman alokasi bantuan. Tim Teknis Direktorat Jenderal menginput data-datanya pada form alokasi bantuan. Jika Tim Teknis Direktorat Jenderal memilih tombol 'Hitung', sistem memverifikasi inputan dan sistem menampilkan perhitungan nilai alokasi. Jika Tim Teknis Direktorat Jenderal memilih tombol 'Simpan', sistem memverifikasi inputan. Sistem menyimpan data laporan pendataan bantuan pada tabel TrAlokasi dan TrDetilAlokasi. Selanjutnya jika Tim Teknis Direktorat Jenderal memilih tombol 'Cetak', sistem menampilkan halaman window print.

Gambar 6 merupakan tampilan dashboard. Pada halaman ini akan ditampilkan: (1) program Bantuan yang dapat diakses per subsektor yang menampilkan informasi rencana, alokasi, dan realisasi per program bantuan; (2) indikator pelaporan bantuan (current period) yang dapat diakses per program bantuan dan per subsektor, yaitu: (a) pelaporan pendataan bantuan. Indikator: persentase perbandingan antara jumlah Gapoktan yang telah memberikan laporan pendataan bantuan dengan jumlah Gapoktan yang telah menerima alokasi bantuan; (b) pelaporan bulanan Gapoktan. Indikator: persentase perbandingan antara jumlah Gapoktan yang telah memberikan laporan bulanan Gapoktan dengan jumlah Gapoktan memberikan laporan pendataan bantuan (dilakukan perhitungan per bulan); (c) pelaporan triwulan Gapoktan. Indikator: persentase perbandingan antara jumlah Gapoktan yang telah memberikan laporan triwulan Gapoktan dengan jumlah Gapoktan memberikan laporan pendataan bantuan (dilakukan perhitungan per triwulan); (d) pelaporan triwulan penyuluh pendamping. Indikator: persentase perbandingan antara jumlah Gapoktan yang telah memberikan laporan triwulan penyuluh pendamping dengan jumlah Gapoktan memberikan laporan pendataan bantuan (dilakukan perhitungan per triwulan). Jika persentase $>75 \%$, indikator akan menunjukkan warna hijau. Jika persentase $50-75 \%$, indikator akan menunjukkan warna kuning. Jika persentase < 50\%, indikator akan menunjukkan warna merah; (3) grafik, antara lain: (a) grafik rencana per program bantuan pada tingkat nasional (sumbu $\mathrm{x}=$ program bantuan, sumbu $\mathrm{y}=$ nilai (Rp)) yang dapat diakses per/bulan; (b) grafik rencana - alokasi - realisasi per program bantuan pada tingkat nasional (sumbu x 
= program bantuan, sumbu y = nilai (Rp)) yang dapat diakses per/bulan; (c) grafik realisasi per program bantuan pada tingkat nasional (sumbu $\mathrm{x}=$ triwulan, sumbu $\mathrm{y}=$ nilai $(\mathrm{Rp})$ ) yang dapat diakses per/tahun; (d) grafik produktivitas pada tingkat nasional (sumbu $\mathrm{x}=$ triwulan, sumbu $\mathrm{y}=$ nilai $(\mathrm{Rp})$ ) yang dapat diakses per/tahun dan per komoditi.

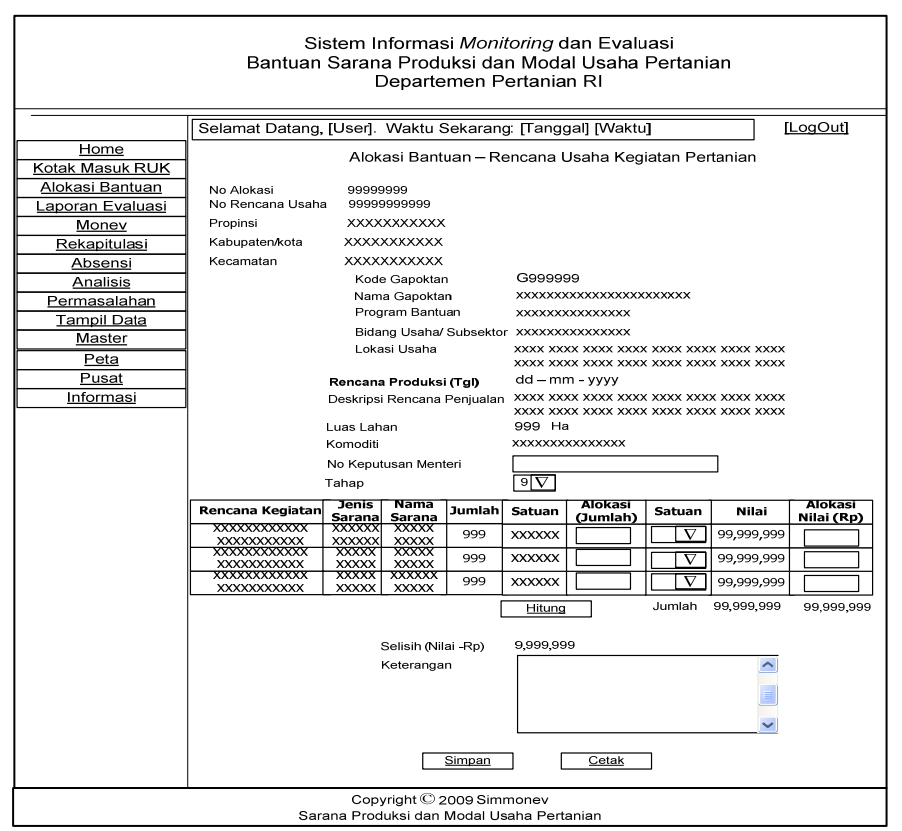

Gambar 5 Rancangan user interface alokasi bantuan sarana produksi dan modal usaha pertanian

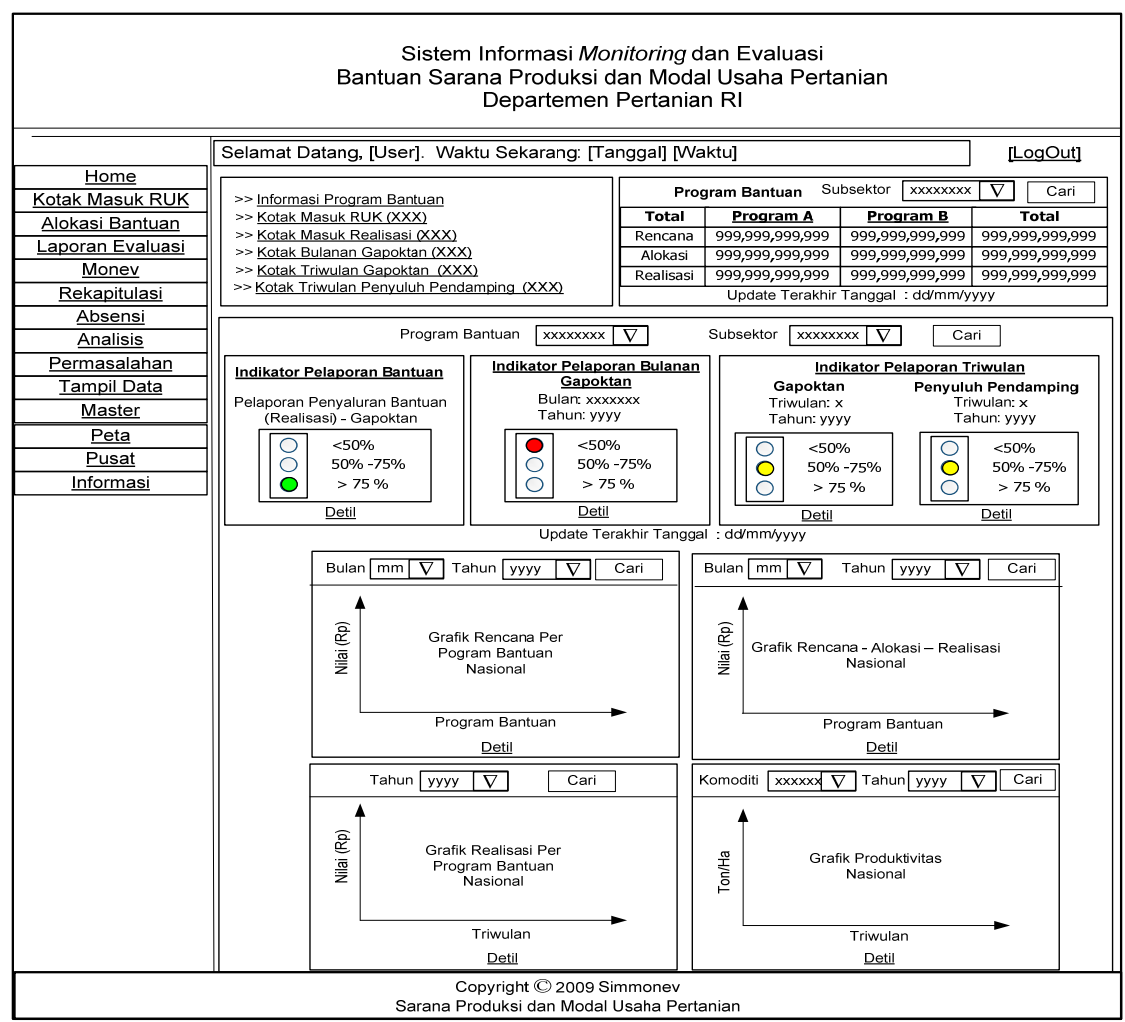

Gambar 6 Rancangan user interface dashboard monitoring bantuan sarana produksi dan modal usaha pertanian 
Pada Gambar 7 sistem menampilkan halaman Laporan Evaluasi tingkat Nasional (secara default akan menampilkan tabel informasi untuk seluruh program bantuan sesuai dengan periode bulan pada saat pengaksesan). Menteri Pertanian dapat memilih subsektor, program bantuan, dan periode. (komoditi hanya dapat dipilih pada laporan evaluasi akhir kegiatan). Tim Teknis Direktorat Jenderal dapat memilih program bantuan dan periode. (komoditi hanya dapat dipilih pada laporan evaluasi akhir kegiatan). Jika Menteri Pertanian atau Tim Teknis Direktorat Jenderal memilih tombol 'Tampilkan', sistem akan memverifikasi inputan.Sistem menampilkan informasi detil laporan evaluasi secara nasional (per propinsi). Jika Menteri Pertanian atau Tim Teknis Direktorat Jenderal memilih tombol 'Pilih Seluruh', akan ditampilkan check box dalam kondisi checked. Jika memilih 'Tidak Pilih Seluruh', akan ditampilkan check box dalam kondisi unchecked (hal ini akan berimplikasi pada grafik yang akan ditampilkan pada saat tombol 'Grafik' dipilih). Jika Menteri Pertanian atau Tim Teknis Direktorat Jenderal memilih tombol 'Cetak', sistem menampilkan halaman window print. Jika Menteri Pertanian atau Tim Teknis Direktorat Jenderal memilih tombol 'Grafik', sistem menampilkan halaman grafik sesuai dengan data yang dipilih. Jika Menteri Pertanian atau Tim Teknis Direktorat Jenderal memilih link nama propinsi, sistem menampilkan halaman Laporan Evaluasi pada tingkat Propinsi sesuai dengan link propinsi yang dipilih.

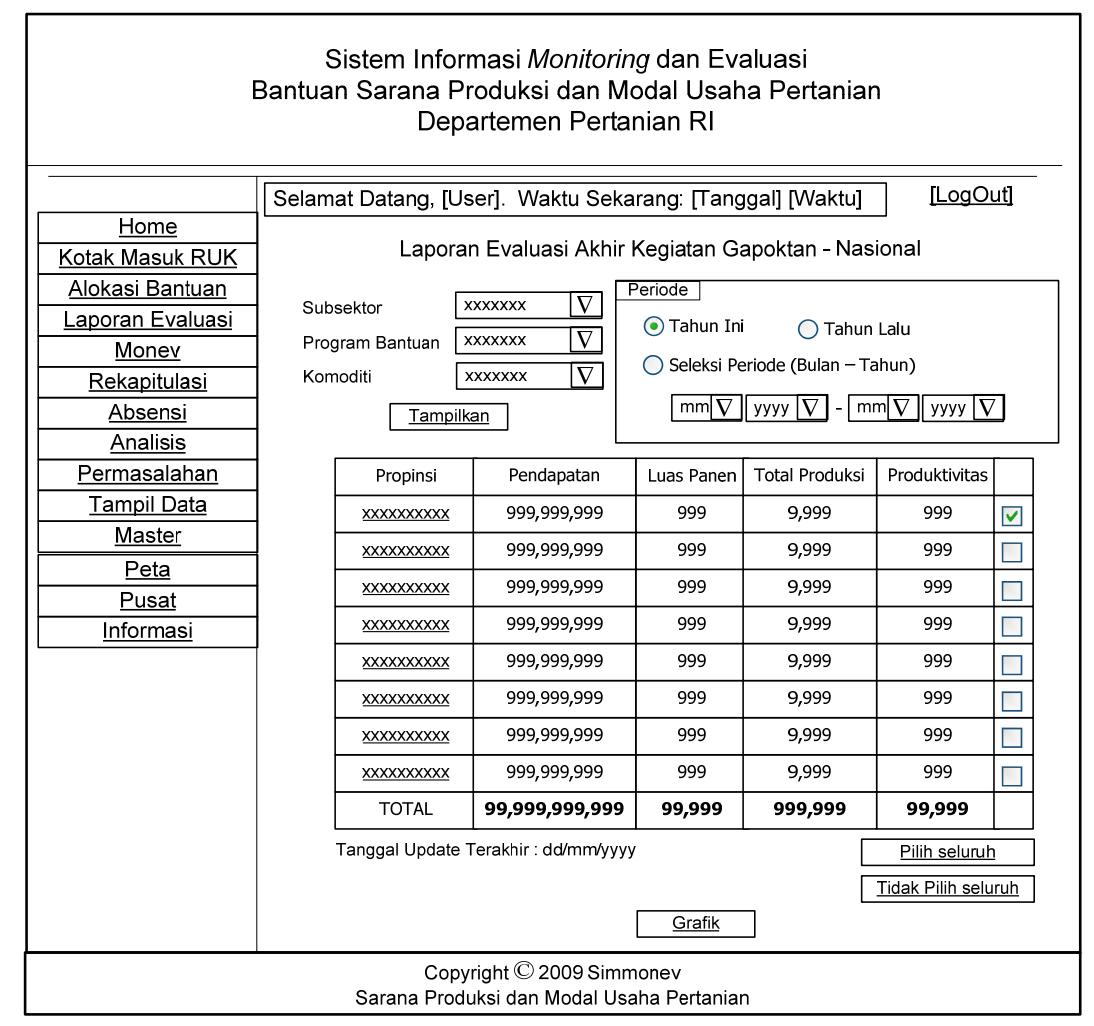

Gambar 7 Rancangan user interface dashboard laporan evaluasi kegiatan

Pada Gambar 8 sistem menampilkan halaman Rekapitulasi tingkat Nasional. Menteri Pertanian dapat memilih subsektor, program bantuan, tipe laporan (rencana kegiatan, alokasi, pendataan bantuan, bulanan Gapoktan, triwulan Gapoktan, triwulan penyuluh pendamping), agregasi (tinggi, rendah, rata-rata, jumlah), tipe grafik (batang atau garis), perbandingan (periode, rencana alokasi, alokasi - realisasi), dan periode. Tim Teknis Direktorat Jenderal dapat memilih program bantuan, tipe laporan, agregasi, tipe grafik, perbandingan dan periode. Menteri Pertanian atau Tim Teknis Direktorat Jenderal memilih tombol 'Tampilkan', kemudian sistem akan memverifikasi inputan. Sistem menampilkan informasi detil laporan rekapitulasi dan grafik secara nasional (per propinsi). Jika Menteri Pertanian atau Tim Teknis Direktorat Jenderal memilih tombol ‘Cetak', sistem 
menampilkan halaman window print. Jika Menteri Pertanian atau Tim Teknis Direktorat Jenderal, memilih link nama propinsi, sistem menampilkan halaman rekapitulasi propinsi sesuai dengan link propinsi yang dipilih.

\section{Component Architecture}

Struktur arsitektur komponen yang dipilih adalah client-server dengan pola Local Presentation. Di Client (Kabupaten/Kota, Propinsi, dan Pemerintah Pusat) hanya terdapat User Interface yang akan melakukan request dan System Interface yang akan menyediakan akses terhadap function di server yang akan memproses dan memberikan respons yang diminta. Hal ini bertujuan untuk menjaga konsistensi data transaksi karena sistem dapat diakses melalui web oleh beberapa client yang berada pada lokasi yang berbeda. Data hanya terdapat di pusat karena antara tiap bagian perlu adanya integrasi, oleh karena itu model hanya akan terdapat di server untuk menjaga konsistensi data, dapat dilihat pada Gambar 9.

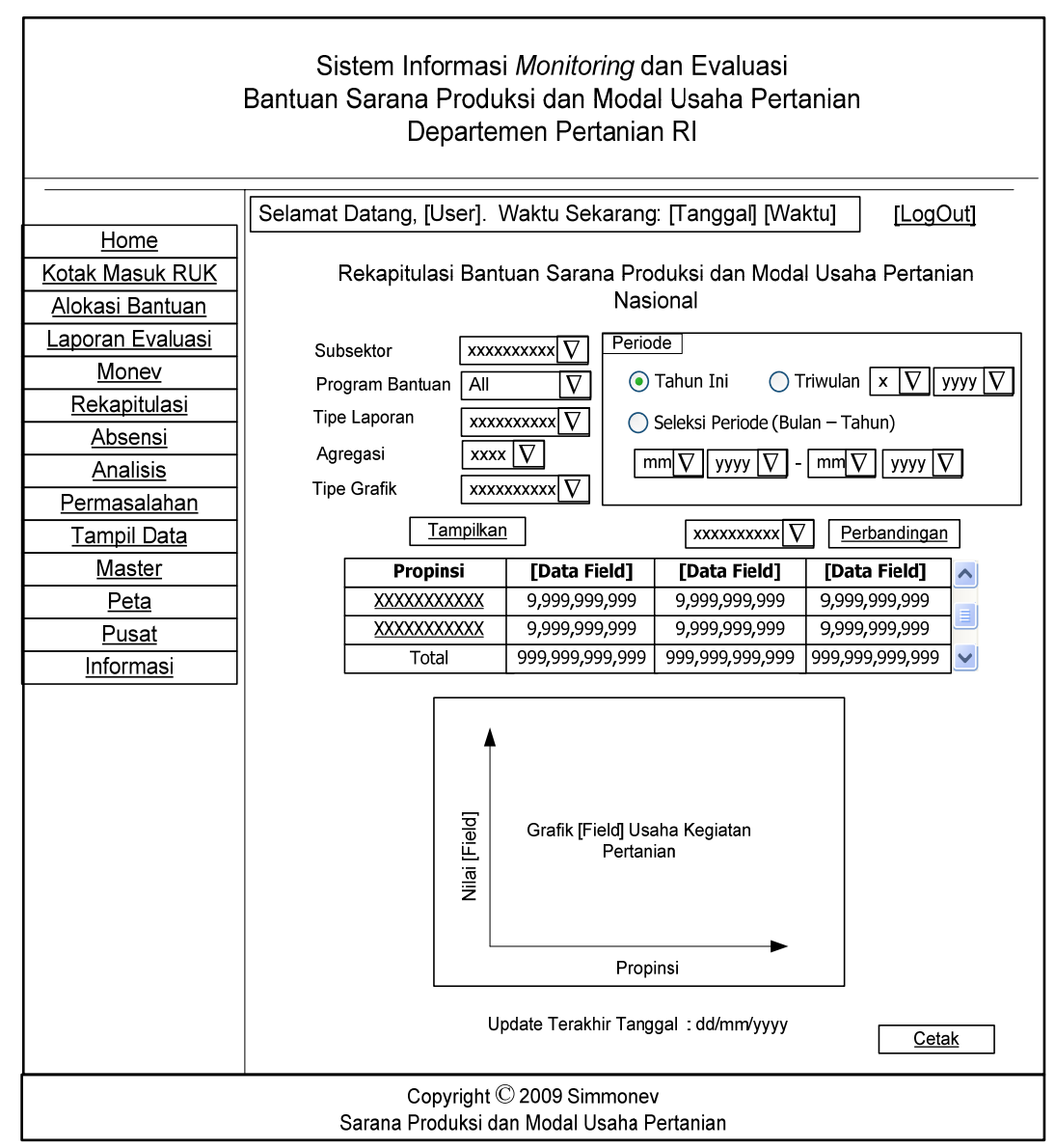

Gambar 8 Rancangan user interface rekapitulasi bantuan pertanian 


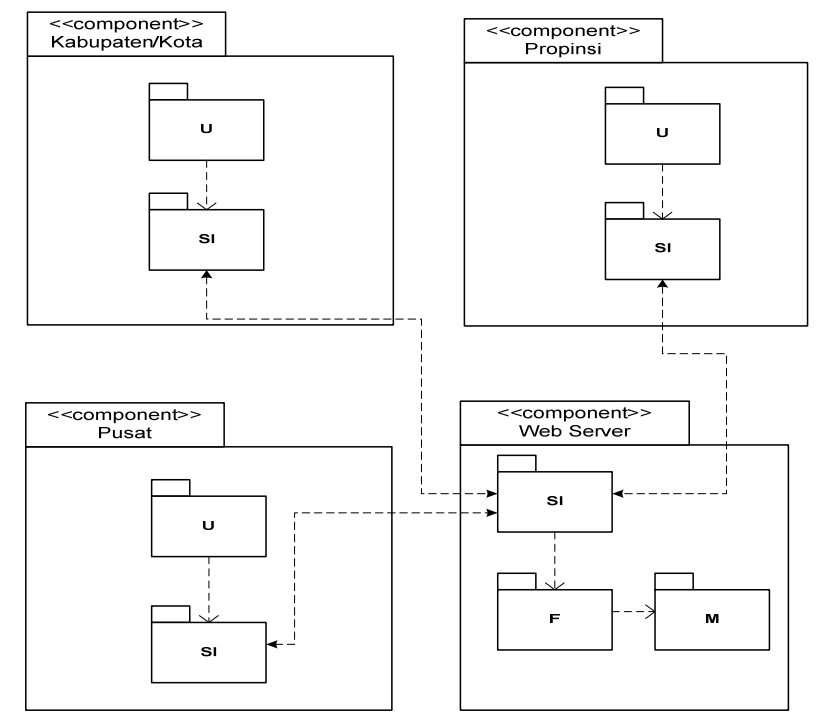

Gambar 9 Component diagram sistem informasi monitoring dan evaluasi bantuan sarana produksi dan modal usaha pertanian.

\section{PENUTUP}

Berdasarkan hasil analisis dan perancangan sistem informasi monitoring dan evaluasi bantuan sarana produksi dan modal usaha pertanian ini, simpulan yang dapat ditarik adalah: Sistem informasi monitoring dan evaluasi yang dirancang dapat menyediakan akses informasi yang sesuai dengan kebutuhan masing-masing pihak yang terlibat dalam kegiatan monitoring dan evaluasi bantuan sarana produksi dan modal usaha pertanian pada tahap ex-ante, on-going, dan ex-post sehingga memudahkan kegiatan administratif dan meningkatkan kinerja Pemerintah Pusat (Menteri Pertanian dan Tim Teknis Direktorat Jenderal), Tim Pembina Dinas Pertanian Propinsi, dan Tim Teknis Dinas Pertanian Kabupaten/Kota.

Berikut adalah beberapa saran yang diharapkan dapat berguna untuk pengembangan sistem informasi monitoring evaluasi bantuan sarana produksi dan modal usaha pertanian: Perlunya pengembangan DSS (Decision Support System) untuk mendukung proses seleksi Gapoktan sebagai penerima bantuan sarana produksi dan modal usaha pertanian secara profesional, proporsional, dan akuntabel . Disamping DSS, perlu juga dipertimbangkan adanya pengembangan EIS (Executive Information System) yang dapat diintegrasikan dengan DSS untuk memberikan berbagai informasi yang disajikan dengan penambahan informasi eksternal terkait dengan program bantuan pertanian (sarana produksi dan modal usaha pertanian).

\section{DAFTAR PUSTAKA}

Basili, V. R., Caldiera, G. (1995). Improve software quality by reusing knowledge and experience. Sloan Management Review, 37(1), 55-64.

Daniel, M. (2004). Pengantar Ekonomi Pertanian. Jakarta: Bumi Aksara. Information Systems, 26(3), 205-236. 
Kementrian Pertanian RI. (2008). Petunjuk Pelaksanaan Pemberdayaan dan Pengembangan Usaha Agribisnis, 2008. Jakarta: Kementrian Pertanian RI.

Rainer, R. K., Turban, E., \& Potter, R. E. (2007). Introduction to Information Systems: Supporting and Transforming Business. New Jersey: John Wiley \& Sons.

Satzinger, J. W., Jackson, R. B., \& Burd, S. D. (2005). Object Oriented Analysis and Design with the Unified Process. Massachusetts: Course Technology.

Vassiliadis, P., Quix C., Vassiliou Y., \& Jarke M. (2001). Data warehouse process management.

Vincent, H. (2006). Undestanding e-government (Information Systems in Public Administration). New York: Taylor \& Francis Books. 